\title{
APLICAÇÃO DE ADSORÇÃO PARA REMOVER AMÔNIA DE EFLUENTES SUINÍCOLAS PRÉ-TRATADOS
}

\section{Martha Mayumi Higarashi*, Airton Kunz e Rosemari Martini Mattei}

Empresa Brasileira de Pesquisa Agropecuária, Centro Nacional de Pesquisa em Suínos e Aves, CP 21, 89700-000 Concórdia - SC, Brasil

Na Tabela 1 publicada no vol. 31, n. 5, 1156-1160, na página 1157, aonde se lê Sólidos Totais - 2.793 g L ${ }^{-1}$ e Sólidos Fixos - 2.013 g L L , leia-se Sólidos Totais - 2,793 $\mathrm{g} \mathrm{L}^{-1}$ e Sólidos Fixos - 2,013 g L ${ }^{-1}$. 